\title{
The lligan City Public Library and Services: Its Community Sectors' Awareness and Responses
}

\author{
Virginia R. Mercado-Garcia
}

Registered Librarian, Bachelor of Arts in English, Master in Library Science Librarian IV, Iligan City Public Library, Iligan City, Philippines viamercado@yahoo.com

\section{Gaudencio M. Alaya-ay, Jr.}

\author{
Registered Librarian, Bachelor of Arts in English \\ Master of Arts in Education, PhD in Educational Planning and Management \\ Librarian II, Iligan City Public Library, Iligan City, Philippines \\ gaudenciojr.alayaay@yahoo.com.ph
}

\section{Doi:10.5901/jesr.2013.v3n3p227}

\begin{abstract}
This descriptive study was conducted in Iligan City, northern coast of Mindanao, occupying the Southern portion of the Philippine archipelago. This is a survey of 462 respondents coming from the cross-section of the communities during the Calendar Year 2012 to assess if the City Public Library was able to level the library services as based on its collections. Moreover, personal interviews were conducted, daily statistics on library users was utilized, and survey questionnaire on awareness, patronage, gauge of services against needs, other information sources information needs, and library resources were done in data gathering. Findings revealed that of the 313,291 total population (as of 2012 census) which is the target users of the city public library, only 8,397 or $2.68 \%$ actually made use of its library services. Out of this, an overwhelming majority or $88.46 \%$ are students, followed by the children with $4.74 \%$ and the professionals with $3.87 \%$ patronage. There has been no patronage from the handicaps and inmates and very least from the out-of-school-youth, non professionals, and senior citizens. Factors affecting these wide gaps between the legitimate and the actual users include: awareness in ICPL's existence and the mandate of Republic Act 7743, geographical accessibility, policies of ICPL, library services, and the presence of other information centers within the city. These findings imply that the lligan City Public Library must plan massive reach-out programs in order to bring the library resources closer to all sectors of its intended users which are the whole of the lligan City community.
\end{abstract}

Keywords. Social Sciences, Library Science, Public Libraries, Library Services, Library Users, Descriptive study, Iligan City, Mindanao, Philippines

\section{Introduction}

Historical sketches on libraries show that the library as a component part of the history of civilization, its story interwoven with the story of the people it has served. The needs to which libraries from their earliest existence have responded are as diverse as the conditions out of which they have grown. In the story of libraries, however, certain types of needs recur frequently enough to be identified with each of these types of needs. Many of the basic needs which are served by librarians today- public libraries in particular- such as education, research, information, civic responsibility, aesthetic appreciation, and recreation- are also served by other agencies and groups. The library, in a collective sense, is the agency devoted solely to the purpose of recollecting, making available and securing the widest and most effective use of records of civilization by the society of which it is a part (David, 1979 as cited in by Montebon, 2010). Thus, the need of any highly industrial and technical society, in such a day as this when fast and radical changes are taking place throughout the world, the need for the library is almost without limit (Gates, 1968 as cited in by Lopera, 2011).

To realize the above presentations, the Republic Act 411 of 1949 which called for the establishment of 1,000 new town libraries over a period of five (5) years and which has been expanded by R.A. 7743 of 1994 was created which mandates that as an "indispensable societal instrument, public libraries are committed to provide an equal and easy access to information resources and stock of knowledge which are the key factors towards an improved quality of life and the country's economic progress and global excellence." This Act provides for the establishment of congressional, city, and municipal libraries and barangay reading centers throughout the Philippines, appropriating the necessary funds 
thereof and for other purposes.

Generally, a public library aims to provide information services to promote education of people of all sectors in the community to provide materials for wholesome reactions and useful use of leisure time of the people. This means that the public library is mandated to serve not only the students and the professionals but is equally mandated to serve the street children, the out-of-school youth and the non-professionals.

Realizing this and the need for a central source of information at the city level, the lligan City Public Library (ICPL) was founded as a project by the Rotary Club of lligan in Rotary Year 1966-1967. Since then, it has been in existence for this purpose.

\section{Framework}

The public library's most vital function remains as a prime repository of national heritage. Its collection mirrors the national psyche and provides an identity common to a people, their way of life, ideas, and aspirations. Its main obligation is to make national culture accessible to all classes of people in the society. This task includes the collection, organization, display, dissemination, and preservation of materials reflecting the national heritage but making the people better understand and appreciate this heritage.

Another important role played by the public library in enriching culture is promoting the use of the national heritage. Priority in acquisition is given to works written in the language and the vernaculars. Works of local writers are also given preference in the library's acquisition program. The library can help elevate the national language for serious works at the same time in bringing valuable writings to the segment of the reading public, which would prefer it. Thus, the so-called local history collection, which is the incumbent function of the public library. A more specific purpose of a public library is to put together, preserve and administer books and related educational materials in organized collections, to promote through guidanc3 and encouragement, an enlightened citizenry and enriched personal lives (David, 1979) as cited in by (La Cerna, 2009).

In actual practice, utilization of library services is often selective maybe due to the method by which library services are delivered, inadequacy of library resources (which could be due to budgetary constraints), geographical location, inadequacy of manpower resources, and lack of community awareness or responsiveness to the services offered. Or maybe there is a failure or oversight on the part of the librarians to meet the very stated mission and vision for which the public library is being created.

To understand the process of librarianship, we must begin to devote greater effort to examining and re-examining societal needs as to the fountainhead for the services and materials of the library. Information needs of a society change in accordance with the development that is taking place in the nation. As a contributor towards national development, libraries should act as catalyst of change. One of the roles of libraries is to extend the benefits of global information resources to the local communities through the introduction of new technologies in libraries (Jaafar, 1996 as cited in by Fajardo, 2009). Until and unless the problems are tackled at the grassroots level, and unless the current trends in library servicing the cooperative ventures and networking be embraced into the mainstreams of library servicing, it is unlikely that the situation will improve and it is this light that libraries and librarians could continue to overcoming the problems through the intelligent use of information (Yaacob, 1996 as cited in by Yancey, 2011).

\section{Objectives of the Study}

This study aims to assess the role of the lligan City Public Library towards the lligan City community as its users. It also intends to recommend strategies to solve or narrow the gap between the target and actual users of the lligan City Public Library and to propose programs to reach out to the majority of the identified unreached sector of the community.

\section{Materials and Methods}

To cover all the diverse sectors of the lligan Community, the respondents were categorized as follows: children, students, out-of-school youth, professionals, non-professionals, senior citizens, handicapped, inmates, and n.e.c. ( or none elsewhere classified). Children below 4 years of age were not included since preparatory school age usually begins at 4 . These were further classified into legitimate or target users and the actual users. Though lligan City has quite number of manufacturing industries, the industrial workers' sector was excluded in this study because a portion of it is already reflected in the professional sector. 
Since distance is one of the determinants of one's visit or patronage of a public library, the forty-four (44) barangays were first divided into two (2) categories: accessible and inaccessible. Then, selection of respondents was made from six (6) accessible barangays (Poblacion, Mahayahay, Saray-Tibanga, Tipanoy, and Ubaldo Laya) and three (3) inaccessible barangays (Mandulog, Dulag, and Digkilaan). Random samples of $20 \%$ from each sector of the actual public library users extracted and used as respondents of this study.

Table A. Sectoral Distribution of Population

\begin{tabular}{|l|c|c|c|c|c|c|}
\hline \multirow{2}{*}{ Community Sectors } & \multicolumn{2}{|c|}{ Target Users of Iligan City Public Library (ICPL) } & \multicolumn{2}{c|}{ Respondents } \\
\cline { 2 - 7 } & $\begin{array}{c}* \\
\text { Legitimate } \\
N=313,291 \\
(2012 \text { Census })\end{array}$ & $\%$ & $\begin{array}{c}* * \\
\text { Actual } \\
(\mathrm{n}=8,397)\end{array}$ & $\%$ & $\begin{array}{c}\text { Patrons } \\
20 \% \text { of } \\
\text { Actual } \\
\text { Users }\end{array}$ & $\begin{array}{c}\text { Non- } \\
\text { Patrons }\end{array}$ \\
\hline Children & 64,500 & 20.59 & 398 & 4.74 & 80 & 16 \\
\hline Students & 55,450 & 17.70 & 7,248 & 88.46 & 150 & 50 \\
\hline Out-of-School Youths & 17,900 & 5.71 & 53 & 0.63 & 11 & 5 \\
\hline Professionals & 17,535 & 5.60 & 325 & 3.87 & 65 & 15 \\
\hline Non-Professionals & 29,237 & 9.33 & 95 & 1.13 & 20 & 10 \\
\hline Senior Citizens & 17,265 & 5.51 & 98 & 1.17 & 20 & 10 \\
\hline Handicaps & 1,400 & 0.45 & 0 & 0 & 0 & 5 \\
\hline Inmates & 500 & 0.16 & 0 & 0 & 0 & 5 \\
\hline n.e.c. & 109,504 & 34.95 & & & & \\
\hline
\end{tabular}

Legend:

n.e.c. - none elsewhere classified

* $\quad$ - Taken from the 2012 Iligan City Socio-Economic Profile

** - Taken from the Users' Logbook of ICPL

Survey questionnaires and personal interview were the tools used in data gathering. The survey questionnaire consisted of awareness, patronage, and gauge of services against needs, other information sources, information needs, and library source. The personal interviews were made on some patrons of the ICPL, some members of different professional organizations, and other sources to determine the type of services they extended to the public. The daily sitting statistics was used in the data gathering.

From the daily loan and sitting statistics maintained by the ICPL, the following information were obtained: a) type of materials borrowed; b) subject inquiries, which enabled the researcher to determine the actual information needs of the ICPL users from the different sectors of the community. These statistical records showed that the bulk of the ICPL users are students, most of which are from the nearby national high school and the prominent MSU-lligan Institute of Technology. Questionnaires were distributed to the different sectors coming from the different barangays in the city. Of the 500 questionnaires fielded, only 642 were retrieved, utilized, and analyzed. The 2012 Iligan City Socio-Economic Profile from the City Planning and Development Office provided that data about the city's statistical profile.

\section{Results and Discussions}

Table 1: Profile of Difference Between Legitimate and Actual Public Library Users

\begin{tabular}{|l|c|c|c|c|c|}
\hline \multirow{2}{*}{ Community Sectors } & \multicolumn{5}{|c|}{ Target Users } \\
\cline { 2 - 6 } & $\begin{array}{c}\text { Legitimate } \\
(\mathrm{N}=313,291)\end{array}$ & Percent & $\begin{array}{c}\text { Actual } \\
(\mathrm{n}=8,397)\end{array}$ & Percent & $\begin{array}{c}\text { Actual Against } \\
\text { Legitimate }\end{array}$ \\
\hline Children & 64,500 & 20.59 & 398 & 4.74 & 0.62 \\
\hline Students & 55,450 & 17.70 & 7,428 & 88.46 & 13.40 \\
\hline Out-of-School Youths & 17,900 & 5.71 & 53 & 0.63 & 0.30 \\
\hline Professionals & 17,535 & 5.60 & 325 & 3.87 & 1.85 \\
\hline Non-Professionals & 29,237 & 9.33 & 95 & 1.13 & 0.32 \\
\hline Senior Citizens & 17,265 & 5.51 & 98 & 1.17 & 0.57 \\
\hline Handicaps & 1,400 & 0.45 & 0 & 0 & 0 \\
\hline
\end{tabular}




\begin{tabular}{|c|c|c|c|c|c|}
\hline Inmates & 500 & 0.16 & 0 & 0 & 0 \\
\hline n.e.c. & 109,504 & 34.95 & & & \\
\hline TOTAL & 313,291 & $100 \%$ & $\begin{array}{c}8,397 \\
(2.69 \%)\end{array}$ & $100 \%$ & $17.06 \%$ \\
\hline
\end{tabular}

Out of the total legitimate or target users $(313,291)$ the actual public library patrons constitute only 8,397 or $2.68 \%$ and from this percentage total of actual users, the biggest number of clients were the students. It should be noted that however their big patronage, they only represent $15.48 \%$ of the entire student population. It is still insignificant result which could be attributed to the fact that the schools where the students belong have their own school or academic libraries where they are the legitimate users.

The next bigger number of library patrons were the children with 398 which is $4.74 \%$ of the actual users and yet only $0.62 \%$ against the total $(64,500)$ children population. At the city public library, there is a special section for the children. However, due to the teeming presence of high school and college students, the children's section was usually occupied even though the librarians did not reach out or orient parents to bring their children to enjoy the library's children's sources.

The professionals ranked third in its patronage of the public library constituting 325 or $3.87 \%$ actual users out of the total patrons of 8,397 . Again, it should be noted that this number is only $3.13 \%$ of the total 17,535 professionals in lligan City. In this study, statistics shows $0.63 \%$ (53 out of 8,397) patronage came from the out-of-school youth population. Aside from them, the next least users were the non-professionals. They include the plain housewives, farmers, fishermen, drivers, vendors, etc. Information says that it is the third biggest sector in the community, yet there are only $95(1.13 \%$ actual users) of the total $(29,237)$ non-professionals population.

There was no patronage from the handicaps and the inmates, apparently because there was no special reach-out programs provided for them. The public library has the collections of Braille materials for the blind, however, there were no trained library personnel to put them into use, and hence, they just kept the materials unused.

In one hand, age has long been considered a retardant to library use. Older people used the library less than young people did as they reached toward retirement, much of their decline to visit the learning environment because some other priorities (http:///www.statelibrary.dcr.state.nc.us/jnr/pldevv2.html; retrieved 2006). This could be the reason why there were only $1.17 \%(98)$ senior citizen users against its total $(17,265)$ population. Another possible reason was the fact that the public library did not have much to offer to them like a music section, where the aged could listen to their old favorite tunes; the memorabilia corner where they could muse over; the senior citizen forum where they could while away their boring free times at home; and the like, and if at all there is a faint semblance of this kind of service at the public library, not ever announced to the aged sector at all.

On the other hand, this profile is corroborated by the findings of (Afan, 1983) as cited in by (Oro, 2008) where the biggest users percentage-wise, of the public library were the high school students, followed by the college students, the children, the professionals and the last, the out-of-school youth. In connection further to the aforesaid findings, Muñasque's paper presented at the $7^{\text {th }}$ Congress of Southeast Asian Librarians, disclosed that public library use is at best reaching only $7 \%$ of the population, a fact which does not speak well of public librarianship. This picture does not exclude in any way the public library of Iligan City, Philippines.

Table 2: Awareness Profile of Non-Library Patrons

\begin{tabular}{|l|c|cc|cc|}
\hline \multicolumn{1}{|c|}{$\begin{array}{c}\text { Community Sectors } \\
\text { (Non-Patrons) }\end{array}$} & Respondents & \multicolumn{2}{c|}{ Existence } & \multicolumn{2}{c|}{ Mandate } \\
Yes & & No & \multicolumn{2}{c|}{ Yes } \\
\hline Children & 16 & 2 & 12 & 0 & 16 \\
\hline Students & 50 & 2 & 3 & 18 & 32 \\
\hline Out-of-School Youth & 5 & 14 & 1 & 14 & 1 \\
\hline Professionals & 15 & 5 & 5 & 3 & 7 \\
\hline Non-Professionals & 10 & 3 & 7 & 4 & 6 \\
\hline Senior Citizens & 10 & 1 & 4 & 0 & 5 \\
\hline Handicaps & 5 & 2 & 3 & 1 & 4 \\
\hline Inmates TOTAL & 5 & 53 & 63 & 40 & 76 \\
\hline
\end{tabular}

As shown in the table, there is a wide gap in the profile of actual against legitimate or target users of the public library. In 
its existence, and of the mandate of Republic Act 7743 sources of data on this particular portion of the research are the 116 legitimate but non- patron respondents. For obvious reasons, the usual library clients are excluding. On mere awareness on the city's public library presence, almost half of the respondents replied positively (22 out of 50), while almost half of the professional respondents indicated its awareness. The least aware respondents were the handicaps and then inmates. Totally, there was an almost equal distribution of responses as their respondents' awareness on the existence of the public library as pointed by the findings of the survey.

Nevertheless, majority (76 or $65.55 \%$ ) of them were not aware of the mandate of the Republic Act 7743. Obviously, the most informed sectors were the professionals and the students, while the least informed were the persons with disability or handicapped, the out-of-school youth, the inmates, and the children. Gozo (1994) as cited in by Nunag (1998) disclosed similar results that majority of the residents of her hometown were not aware of the existence of their municipal and/or city public library.

Table 3: Respondents' Reasons for Awareness of the Public Library Existence

\begin{tabular}{|cl|c|c|c|}
\hline & Reasons & Frequency & Percent & Rank \\
\hline 1. & It is near my residence/office/place of work. & 206 & 51.63 & 1 \\
\hline 2. & Through a friend/relative/associate or other librarian/s. & 104 & 22.30 & 3 \\
\hline 3. & Others & 89 & 26.07 & 2 \\
\hline \multicolumn{2}{|c|}{ Total } & 399 & $100 \%$ & \\
\hline
\end{tabular}

The 399 respondents as to how they became aware of the public library's existence had cited several reasons. More than one-half of them (51.63\% leaned about the city public library because it is located near their school, residence, office or place of work. This explains why most of its users or clients are the students from the nearby schools. This also shows that these clients are mostly from barangays within the vicinity of the public library. Others answered that they became aware of the public library because it is located along the road where it is visible to passersby, they learned about it through the radio or from their children who regularly researched at the said public library.

This would imply that in the absence of reach-out services of the public library was among the reasons why most of the legitimate or target users have not been aware of its existence.

Table 4 : Respondents' Reasons for Unawareness of the Public Library Existence

\begin{tabular}{|c|c|c|c|}
\hline Reasons & Frequency & Percent & Rank \\
\hline 1. Have not heard about it/nobody told me about it & 9 & 16.99 & 2 \\
\hline 2. I do not know what it is & 3 & 5.66 & 3 \\
\hline 3. I though it is the library of the nearby public high school & 39 & 73.58 & 1 \\
\hline 4. No answer & 2 & 3.77 & \\
\hline Total & 53 & $100 \%$ & \\
\hline
\end{tabular}

The continuous presence of so many high school students from the nearby school which constitute $73.58 \%$ led to the people's expectation that such is a school library. In fact, some, it not most students of the said school shared the same opinion. While some (16.99\%) did not hear about the existence of a public library in the city, $5.66 \%$ did not what it is all about. This should pause a big a challenge for the city public librarians. Massive out-reach program to announce that the Iligan City Public Library is existed for the unreached clients, to justify the vision and mission for which it was created. Sanchez (1976) as cited in by $($ Sardo, 2005) remarked that it is not enough that the government plan for the availability of information resources but users of information should be informed that they exist and should know how to obtain them.

Table 5 : Non-Patrons' Willingness Profile to Avail of Public Library Services Once Given Orientation

\begin{tabular}{|c|c|c|c|}
\hline & Frequency & Percent & Rank \\
\hline Yes & 95 & 81.90 & 1 \\
\hline No & 18 & 15.52 & 2 \\
\hline No answer & 3 & 2.58 & 3 \\
\hline Total & 116 & $100 \%$ & \\
\hline
\end{tabular}

Geographical accessibility from the target users' residence, school, or place of work is another factor that inhibits coming 
in to avail of the library resources. The nature of library services in distant barangays or in the rural areas presents a unique challenge towards information service. The major hindrance in catering to these other legitimate users is how to get the resources to the people who are wildly scattered. Despite this imposing hindrance, 95 or $81.90 \%$ of the 116 nonpatrons of the public library were still willing to avail of its library services when oriented of what their public library has for them. This is a good indication of the people's thirst for information that can be quenched by the resources found in the library (INFLANET, 2000).

Considering the limited resources (logistically and manpower) of the public library, this restraining factor really poses a problem. In fact, this is one of the reasons why the 18 respondents were not willing or were not interested to avail the public library's services even if they are oriented of the privileges as mandated by the Republic Act 7743 .

Table 6 : Reasons of Non-Willing Legitimate Users to Avail of Public Library Services Despite of the Orientation

\begin{tabular}{|c|c|c|c|}
\hline Reasons & Frequency & Percent & Rank \\
\hline 1. I am too busy/no time to go there & 7 & 38.89 & 1 \\
\hline 2. Too far from my school/residence/ place of work & 6 & 33.33 & 2 \\
\hline 3. I do not know how to read and write & 2 & 11.11 & 4 \\
\hline 4. Not interested & 3 & 16.67 & 3 \\
\hline Total & 18 & $100 \%$ & \\
\hline
\end{tabular}

Being so busy thus having no time to go or visit a library was the reason of $38.89 \%$ of the respondents. While 6 or $33.33 \%$ mentioned prohibitive distance, which makes it possible to go the public library, $16.67 \%$ manifested no interest at all. The least reason was illiteracy. These reasons for unwillingness should be contained in order for these members of the community to become active users of the information sources (Galapin, 2000).

Table 7 : Non-Patrons' Reasons for Not Using the Public Library

\begin{tabular}{|c|c|c|c|}
\hline $\begin{array}{c}\text { Reasons } \\
\text { Policy Restrictions: }\end{array}$ & Frequency & Percent & Rank \\
\hline 1. Not allowed inside/parents or teachers did not bring us there. & 10 & 8.62 & 5 \\
\hline 2. I am not allowed to borrow or bring home books. & 12 & 10.34 & 4 \\
\hline 3. Library hours do not suit my schedule. & 26 & 22.41 & 2 \\
\hline 4. Library collections/services are not suitable for my needs. & 3 & 2.59 & 9 \\
\hline 5. No orientation. & 40 & 22.41 & 1 \\
\hline $\begin{array}{l}\text { Acquisition Policies: } \\
\text { 6. No computer/limited on high technology information sources. }\end{array}$ & 15 & 12.93 & 3 \\
\hline 7. Negative attitude of librarians & 5 & 10.34 & 6 \\
\hline 8. Others. & 4 & 3.45 & 9 \\
\hline 9. No answers. & 1 & 0.86 & 10 \\
\hline Total & 116 & $100 \%$ & \\
\hline
\end{tabular}

Policies are primarily established to serve as guidelines in the implementation of a goal or objective. In a library, public library in particular, certain policies are also observed to help the librarians and the patronizing public. It is not however the intention of library administrators to restrict the users' privileges in availing of the services which in the first place are there for them to make use of. Table 7 presents the reasons why the 116 non public library patron respondents did not avail of its library services.

No orientation or non-awareness of the privileges stated in the mandate of Republic Act 7743 was the primary reason why the 40 or $34.49 \%$ respondents were not patronizing the public library. Ranking second is the library policy on library hours which do not conform with the $260422.41 \%$ respondents' own schedule and third, is the non-availability of new high technology sources or access to internet. This is attributed to the fact that with the information revolution, information needed should be made accessible at the easiest and fastest means (Apugan, 1998).

Provision for out-reach programs should be incorporated in the policies of the public library. This refers to the library services which are extended beyond traditional library services and could even go out of the walls of the library building. Mobile libraries are the most effective out-reach program (Afan, 1983) as cited in by (Jaucian, 2003). It is the transportation of books to users by means of special vehicles- a car, a boat, a wagon, or a tricycle constructed for library 
purposes. This has been the recurring wish of the public librarians to have a book mobile. Due to financial and manpower constraints this remains unfulfilled wish. However, efforts have already been exerted and follow-ups with the National Library and other concerned agencies were constantly being made to transform the dream into reality. This will also benefit those who are too busy and have no time to visit the library and those who are located quite far from the library because library services will be brought to them. For the illiterates, adult education programs may not only concern interpreting cultural and recreation programs but it will also provide lifelong education to people (UNESCO, 2004).

In summary, reasons 1-5 all fall under policy restrictions. This contradicts Heintze's opinion that the public library should be "open for use on equal terms to all members of the community, regardless of occupation, the creed or race." At the public library "not being allowed inside" happens only when a would-be client, particularly students, is not able to present an identification card. This is necessary to safeguard library collections from unscrupulous users. Nevertheless, those who explain the necessity of their research yet could not present any form of identification are requested to log-in and are allowed to enter. This usually applies to out-of-school youth, the senior citizens, the unemployed, nonprofessionals, and sometimes the students. Another policy restriction is applied to lending out of library materials. Borrowers are required to apply for the city public library membership card to avail of the lending privileges.

The city public library has a full sitting capacity of 100 users at a time. There were instances when clients, particularly students, came in droves that limit had been set -100 students of the same school at a time. With numerous schools in lligan, the city public library would really came out inadequate in terms of sitting capacity.

The library staff consists of 2 regular licensed librarians, 2 regular and 2 probationary library personnel which have different functions like the administrative, technical, readers', and periodical's services. There is also a clerk, who, aside from the routinely clerical duties, e.g. typing, filing, payroll preparation, etc. also man's the library checkpoint and sometimes substitutes as liaison officer. Another employee is the bookbinder who is at the same time the liaison officer. As such she is always out of the library processing papers at the city hall which results to a voluminous backlog in the binding of serials.

At present, the city public library has a book collection of not less than 12,000 volumes, a regular subscription of 3 titles of national newspaper, 1 tabloid, 2 titles of weekly magazines about international issues, 1 sports magazine, and 1 about agriculture. The library has also regularly receives free subscriptions from government agencies such as the Department of Science and Technology (DOST), IRRI, Commission on Population, etc. Aside from the printed materials, the city public library also has in its holdings of AV equipment such as television, sound system, and videotapes, on various livelihood programs.

Since the bulk of the city public library's clients are students, most of them usually look for copies of their assigned textbooks at the shelves. Failure to find them, they feel the inadequacy of their public library to provide their needs, not knowing that the public library is there only to augment and not to replace the functions of their own school or academic libraries. The city public library is only a division under the City Mayor's Office. As such, it only receives a portion of the budgetary allocation for the whole department. In spite of the inadequacies, however, the 95 or $81.90 \%$ of the nonpatrons, still willing to avail the library's services made known the library services their felt-need.

Table 8 : Actual Services Needed by Non-Patron Respondents

\begin{tabular}{|l|c|c|c|}
\hline \multicolumn{1}{|c|}{ Needed Services } & Frequency & Percent & Rank \\
\hline 1. Educational toys for children. & 4 & 4.21 & 6 \\
\hline 2. Film showing (educational, livelihood programs, entertainment). & 8 & 8.42 & 5 \\
\hline 3. Flexible storytelling/puppet showing/library hours & 26 & 27.37 & 1 \\
\hline 4. Liberal lending/admission policy. & 22 & 23.16 & 2 \\
\hline 5. Accessibility to network information. & 15 & 15.79 & 4 \\
\hline 6. Mobile library. & 18 & 18.95 & 3 \\
\hline 7. Braille, sign language educational materials, etc. & 2 & 2.11 & 7 \\
\hline \multicolumn{1}{|c|}{ Total } & $\mathbf{9 5}$ & $\mathbf{1 0 0 \%}$ & \\
\hline
\end{tabular}

There is a very little difference in the number of respondents who requested the top 3 choices of needed library services: 1) flexible library hours which suggested that the regular hours of $8: 30 \mathrm{am}$ to $11: 30 \mathrm{am}$ and 1:30 pm to $5: 30 \mathrm{pm}$, Monday to Friday be adjusted in such a way that those who cannot come on the scheduled library hours can still be accommodated; 2) liberal lending/admission policy in which referred to the No ID - No Entry" policy be tamed to allow (within the limit of the public library capacity) to see for themselves and make use of the library resources; and 3) mobile library which aims to reach far lung barangays and those who cannot come due to disabilities and other hindrances 
because the role of the public library concerns delivery of information to the whole community (Krishnan, 1996) as cited in by (Hernandez, 2010).

Table 9 : Other Information Centers in Iligan City, Philippines

\begin{tabular}{|c|c|c|}
\hline Information Centers & Technology Available & Updated Holdings \\
\hline Academic Libraries & Computer Units & CD ROMS, Access to Internet \\
\hline Special Libraries & Computer Units & $\begin{array}{l}\text { Information on } \\
\text { Operations/Journals/Legal } \\
\text { Access to Internet }\end{array}$ \\
\hline LRCs/School Libraries & $\begin{array}{l}\text { Computer Units \& other Audio-Visual } \\
\text { Equipment }\end{array}$ & $\begin{array}{l}\text { Visual Aids, Books on Academic Needs, } \\
\text { Access to Internet }\end{array}$ \\
\hline Philippine Information Agency & $\begin{array}{l}\text { Computer Units \& other Audio-Visual } \\
\text { Equipment }\end{array}$ & $\begin{array}{l}\text { CD ROMS, Serials, Books, Pamphlets on } \\
\text { Government Thrusts }\end{array}$ \\
\hline City Tourism Office & Computer Units & $\begin{array}{l}\text { Brochures, Directories, lligan History, } \\
\text { Internet Access }\end{array}$ \\
\hline Maranet & Computer Units & Internet Access \\
\hline Computrade Phils., Inc. & Computer Units & Internet Access \\
\hline Mobilcom & Computer Units & $\begin{array}{l}\text { Teleconferencing, E-mail, Voice \& Data } \\
\text { Communication }\end{array}$ \\
\hline Microtouch Computer System & Computer Units & CD ROMS, Access to Internet \\
\hline Internet Cafes & Computer Units & Access to Internet \\
\hline
\end{tabular}

The last factor that accounts for the difference in the profile of actual against the legitimate or targets public library users is the existence of other information centers within the city. Aside from the public library, there are other information centers in the city of lligan which serve as alternative or sometimes the main source of information of researchers or information seekers.

They are the

1. Academic Libraries which is the primary source of information of students and faculty in the tertiary and graduate levels. In terms of collection, Mindanao State University-lligan Institute of Technology has the biggest volume of materials considering that aside from its main library, it has also a library for every college or department. Aside from its collection of printed materials, it has also several computers with access to information networking. The students are allowed (subject to their rules and regulations) access to the internet for their research and printing for a minimal fee whenever is needed. They also have several CD ROMS which provide updated and fast retrieval of information. Other academic libraries with updated high technology holdings are the St. Peter's College, St. Michael's College, Iligan Capitol College, Lyceum of Iligan Foundation, and lligan Medical Center College. They have computer units which are internet hooked, CD ROMS, and printed materials of varied disciplines;

2. Special Libraries which are maintained by the industrial plants to serve the product needs of their employees. They allow non-employees access to their materials when needed, especially to students whose researches are related to their product operation;

3. Learning Resource Centers/School Libraries which have the collections of Computer Units and other AudioVisual Equipment and books intended for the young users. Some of these are the flip charts, flash cards, various toys, and educational games;

4. Philippine Information Agency (PIA) is a government entity which, as an information center, with these functions: a) to organize, mobilize, supervise, and sustain operations of the Community Development Information Centers (CDICs) in the area; b) to provide public with accurate, timely, and relevant information through print and broadcast media; c) to provide public information assistance through referrals to the concerned government agencies and non-government organization; d) to gather feedback on people's attitude, beliefs, values on government policies, programs, and projects, their needs and other matters affecting public life; e) to serve as the distribution center of information materials; f) to provide library services; g) to conduct communication skills training; and h) to provide and conduct audio-visual services on government programs and projects. It is also serves as venue for conference, dialogues, for training and seminars of government and non-government agencies. In this agency, they include in their collections the CD 
ROMS, various periodical, and books.

5. Public Information Office which is a section in the City Mayor's Office which is responsible for the dissemination of information on the various projects and activities of the city government. The office gives referral services to information seekers as to the proper department of the city government where the information could be obtained. Its collections include records of various activities being undertaken by the city government, especially at the City Mayor's Office.

6. City Tourism Office which is division in the City Mayor's Office, whose principal function is the promotion of the City of Iligan. It has in its collection brochures and directory of lligan's history. Computers are used as communication equipment. Mode of services is through a guided tour around the city, especially to its different beautiful spots.

7. Maranet of MARATel, Computrade Phils., Inc., Mobilcom, and Microtouch Computer System are private and commercial information centers that provide access to information networking for a fee. Other features available teleconferencing, e-mail, voice and data communication. They also have CD ROMS that can be accessed by researchers, again for minimal fee.

8. Internet Cafés are providers of ranges of information which anyone can obtain. Anyone who craves for fast information will visit these one-stop-one- shop centers that provided the World Wide Web to their customers. Most cafes (if not all) provide services like desk publishing, encoding, photo scanning, computer-assisted design (CAD) and computer games. Moreover, one can send mails through the net using the electronic mail or-email and even free and unlimited text messages through websites like the www.unimobile.com. For the information seekers, instead of going to libraries, sometimes with limited and/or outdated books, they simply go to the internet cafés, clicked the mouse and automatically find themselves within the portals of the US Library of Congress or they could choose to interview experts and chat them on any information of interest.

Table 10 : Evaluation of Actual City Library Users on the their Success with the Library Services

\begin{tabular}{|c|c|c|c|}
\hline Evaluation & Frequency & Percent & Rank \\
\hline Always & 166 & 47.98 & 1 \\
\hline Sometimes & 145 & 41.92 & 2 \\
\hline Never & 35 & 10 & 3 \\
\hline Total & $\mathbf{3 4 6}$ & $100 \%$ & \\
\hline
\end{tabular}

Notwithstanding the earlier mentioned factors that account for the differences between the legitimate or target and actual public library users, the 346 patron-respondents fairly evaluated by library services extended to them by the city public library. When asked to evaluate the actual services in response to their actual needs, almost one-half (166 or 47.98) of the actual users manifested satisfaction on the services they are getting as they always find the answers to their queries from its resources or through referrals. Only $10 \%$ were never satisfied, yet they continue to go to the city's public library. The difference between the "always" satisfied and "sometimes" satisfied, however is very slight, (6.06\%) yet this could motivate the public library management to reach out the other legitimate users. If the present form of library services rendered by the public library satisfies the currently served clients, then it would be fulfilling to extend services to the rest of its users (Acedera, 1981) as cited in by (Martinez, 2011).

\section{Conclusions}

With the data presented and analyzed, it is concluded that the unreached sectors of the lligan City community are the handicaps or persons with disability and those sick in the hospitals, the inmates behind prison bars, and a very large portion of the non-professionals, the children, the out-of-school youth and the senior citizens. Since the very large portion of the ICPL's clients is students, most of their information needs are on subject matters relating to their academic research.

\section{Recommendations}


Based on the findings and conclusion of the study, the following strategies are recommended to narrow the gap between the actual and target users, taking cognizant of the presence of other information sources within the city. The focus is on the identified unreached sectors:

1) Reach-out Programs. This is primarily to reach all the 44 barangays of lligan. The most effective out-reach program that can serve the greatest cross-section of the population is the book mobile. It will bring reading materials to the inmates and the reading handicaps, the out-of-school youth, the none=professionals (like the housewives and other) and senior citizens who cannot come to the library for various reasons. Other forms of reach-out programs especially to the children, young adults, and out-of-school youth are storytelling, puppet shows, educational games, toys, realia, film showing, summer workshops, and reading clubs. For the other sectors like the professionals, researchers, etc., the current awareness and SDI will be very helpful;

2) Build Special Collections for the Unreached Sectors. The information should be available to the disabled. Braille for the blinds should be coupled with a trained staff for this to become effective, audio equipment and multi-media CD-ROMS. Sign language for the deaf mute or leisure reading materials in the vernacular which may be solicited and distributed for free to far flung barangays, the sick and inmates.

3) Computerization. This concerns all aspects of librarianship. Fast technical processing of materials means its immediate accessibility to its users. The widespread application of information technology tools should further enhance the role of libraries at least in facilitating a new function to transmit more information to greater and wider network users.

4) Establish Linkages with other Information Centers. With the presence of other information sources within the city, the IPCPL can initiate the effort and act as the center for other libraries or institutions with similar interests. As a starter, a union catalog may be prepared which can be the basis of referrals for materials not available within ones library. Later when the link has been established and institutionalized and all libraries or information centers are fully automated, inter-library cooperation through networking may be realized.

5) An In-depth Follow-up Study to Focus on the following:
a. Student-Users' Profile
b. Barangay-Users' Profile
c. Library Services for the Illiterates
d. Actual Information Needs Profile for Possible Funding Support

6) Facilities of the ICPL should Target to Meet the Users' Needs:
a. Expand the library to accommodate more users
b. Additional personnel to augment the present library staff
c. Special materials and trained personnel for the handicaps and other unreached sectors
d. Vehicle for the book mobile
e. Full implementation of all the public libraries' enabling laws in the country

\section{Acknowledgment}

The researchers wish to extend their gratitude to all those in one-way or the other extended their wholehearted support and encouragement for the completion of this study and finally to GOD for the peace, joy, and glory showered upon Him.

\section{References}

Apugan, M.J.S. 1998 "Computer Application in Special Libraries \& Attitudes of Library-in-Charge (Administrators) Toward Computerization: A Survey." Unpublished Master's Thesis, MSU-IIT, Iligan City.

Fajardo, H.J. 2009 Public libraries: partnership with communities. New York: McGraw-Hill.

Galapin, L.M. 2000 "Why a Public Library is Necessary to Community Education." The Filipino Teacher, 37 (8): 427. Quezon City.

Heintze, I. J. 2006 The Organization of Small Public Libraries. New York: Mcmillan.

Hernandez, S.J. 2010 Serving the Information Needs of Disabled Persons Through New Technology. Manila: AMJ Publishing.

IFLANET. 2000 Revision of IFLA's Guidelines for Public Libraries. http://www. ifla.org/VII/s8proj/gpl.html. (Accessed: March 2, 2006)

Jaucian, S. L. 2003 LGU's Budgetary Allocation and Service Delivery." Unpublished Master's Thesis, University of Nueva Caceres, City of Naga.

La Cerna, M.C.A. 2009 The National Libraries in the New Information Environment: On Target for the 21st Century. Malaysia: Riverside Printing Press.

Lopera, C.L. 2011 Library cooperation and networks. http://www.earthlink.com (Accessed: February 14, 2012)

Martinez, M. M. 2011 Public libraries: supporting learning process. (Accessed: December 28, 2012)

Montebon, F.L. 2010 Library development in the 21th century. McGraw-Hill. 
Muǹasque, N.V. 1987 "Rural Libraries in Southeast Asia: Country Report (Philippines). CONSAL VII. Manila. 15-21 February.

Nunag, E. R. 1998 "Republic Act 411/7743 : The Extent of its implementation in the Province of Zamboanga del Norte." Unpublished Master's Thesis. MSU-lligan Institute of Technology, lligan City.

Oro, E.S. 2008 The Present Experiences of Library and Information Services in Rural Philippines. Quezon City : L \& M Printing Press.

Public Library Development. http:///www.statelibrary.dcr.state.nc.us/jnr/pldevv2.html (Accessed: March 22, 2006)

Ramos, M.A. 2011 Marketing, promotion, and management of learning centers: Paris: UNESCO.

Sardo, A. M. E. 2005 "Camarines Norte Public Library Resources : Status and Availment." Unpublished Master's Thesis, University of Nueva Caseres, City of Naga.

UNESCO. 2004 The Over-all Ideas in UNESCO's Public Library Manifesto. http://www.branford.library.on.ca/UNET/badalona.html (Accessed: March 13, 2006)

Yancey, K. R. 2010 The People's University : our public libraries as site of lifelong learning. http://www.findarticles.com/p/articles Imi_m1254/is_2_37/ai_n13794989 (Accessed: March 16, 2012)

\section{Appendices}

\section{Minimum Standards For Public Libraries In The Philippines}

\section{Introduction}

\section{The Role of the Public Library}

The public library is catalyst in planning for community development and in the continuous education of the citizens of a nation. It serves as an impartial, non-partisan, and non-sectarian agency of information for all people.

Public library services should therefore be free and be made available to everyone throughout the country.

Public library service should aim to:

1. facilitate informal self-education

2. support and complement research in all fields of endeavors

3. provide bibliographic access to the country's information resources

4. provide wholesome recreation and beneficial use of leisure time of the people

\section{Public Library Service in the Philippines}

In the Philippines, public library service in discharged by the National Library which has a dual function, that of a National Library and that of a public library through its Public Libraries Division.

The Public Libraries Division of the National Library takes charge of the organization and supervision of all regional, provincial, city, municipal, and barangay libraries as well as bookmobile services all over the country. It also is responsible in the training and upgrading skills of field librarian as well as non-professional staff of public libraries throughout the country.

\section{Rationale}

Formulating of public library standards reflect concept of public library service and organization so as to stimulate new development and focus attention in the field of librarianship.

Standards are used as administrative guide in planning goals for development and setting directions for the future.

In formulating this minimum standards the aim is to propose a guide that will serve as challenge to those concerned to revitalize public libraries to meet demands and the realities of the present society.

\section{Standard 1. Objectives of the Public Library}

1.1. To provide library and information service responsive to the needs of the community.

1.2. To build within each library and information center about its respective community -- its resources, its history, its people, its customs and traditions, etc.

1.3. To develop with other libraries within each region or province a network op public library service with the regional library or in the lack of it, the provincial library as its center to facilities research and reference needs within the area.

\section{Standard 2. Organization and Management}

2.1. Each public library shall operate under the direct management and supervision of a competent and professionally trained librarian.

2.2. The public library shall operate under the direct supervision of the National Library on matters that affect its resources and services.

2.3. The public library as a local government unit shall have the local executive of the government units as its immediate superior.

2.4. The public library shall be provided with reasonable budgetary appropriations annually to carry out plans and activities effectively.

\section{Standard 3. Library Advisory Board}

3.1 A trisectoral Library Advisory Board shall be established composed of representatives for the civic, religious and government sectors.

3.2 The Library Advisory Board shall assist the librarian in the formulation of policies which aim to bring the library closer to its users.

3.3 The Library Advisory Board could organize a Friends of the Public Library Club to support library projects and activities especially concerning material and financial resources.

Standard 4. Staff

4.1. The public library system should be manned by qualified and professionally staff in order to render adequate service and serve as an effective 
center for culture and information.

4.2. Sufficient numbers of personnel should be hired to obtain quality service.

4.3. There should be clean out delineation of staff duties and responsibilities.

4.4. Size

4.4.1. The number and kinds of positions in a public library will depend on the population being served and the size of the collection.

4.4.2. As a minimum standard, regional, provincial and city libraries should at least have four professional and three supportive nonprofessional staff. On other hand municipal libraries should at least have one professional and one clerical staff for a municipality lower than first class. First class municipalities should have at least 3 professional librarians and as many supportive staff as needed.

4.4.3. Since barangay libraries in a municipality are directly under the municipal librarian, 2 supportive staff should be the required minimum number of personnel.

4.4.4. The increase in the number of staff shall depend on the number of increase in population of the community served. For every 4.5. Qualifications increase of 50, 000 people in the community a corresponding increase of 1 professional and 1 supportive staff are suggested.

4.5.1. Professional librarian are individual with any of the following degrees:

4.5.1.1. Bachelor of Library Science or Information Science

4.5.1.2. Bachelor of Science in Library Science or Information Science

4.5.1.3. Bachelor of Science in Education major in Library Science

4.5.1.4. Bachelor of Science in Education with Specialization in Library Science

4.5.1.5. Bachelor of Arts major in Library Science

4.5.1.6. Master of Library Science or Information Science

4.5.1.7. Master of Arts in Library Science or InformationScience

4.5.1.8. Master of Science in Library Science or Information Science

4.5.2 They could be assigned any of the following titles depending on educational attainment, experience and available positions.

4.5.2.1. Superintendent of Libraries

4.5.2.2. Director of Libraries

4.5.2.3. Chief Librarian

4.5.2.4. Head Librarian

4.5.2.5. Supervising Librarian

4.5.2.6. Senior Librarian

4.5.2.7. Librarian

4.5.2.8. Cataloger

4.5.3. Supportive Staff

4.5.3.1. Technical staff - should either as BSE or AB minor in library science. They could be appointed as junior librarians.

4.5.3.2. Clerical staff - should have taken exam special studies in Secretarial Science.

4.5.3.3. Library Aides - should at least have finished two years of college or have had at least two years experience working in a library:

4.6. Civil Service Eligibilities

4.6.1. Professional librarians are required to have had passed the Librarian or Supervising Librarian examination or Career Service Professional Examination, pending passage of the Professionalization Bill in Congress, in which case no librarian shall be appointed to professional position until properly licensed by the proposed Board for Librarians.

4.6.2. Supportive staff are required to have passed the sub-professional examination.

4.7. Salary

4.7.1. Salary is undoubtedly the major consideration which attraction an intelligent professional staff.

4.7.2. Heads of Libraries (Regional, Provincial, City \& Municipal) are to be considered on the level of assistant corresponding to the position.

4.7.3. Other personnel follows accordingly.

4.8 Staff Development

4.8.1. To foster intellectual development and update knowledge and skills in librarianship it is necessary to send public librarians and other supportive technical personnel to seminars, conferences, and in-service training programs when necessary and budgetary appropriations should be set aside for this matter.

4.8.2. Scholarship grants should be given to deserving ones when available.

\section{Standard 5. Budget}

5.1. The library shall be provided with an adequate, realistic, annual budgetary appropriations of the local government unit to which it belongs.

5.2. The head librarian shall prepare the annual budget in consultation with local budget officer and shall exercise full control over its expenditures accordingly to procedures followed by the local government unit and COA.

5.3. The library budget shall cover the following:

5.3.1. Personal Services

5.3.1.1. Salaries of personnel

5.3.1.2. Adequate funds for travel to attend seminars, conferences, etc. either held locally and / or abroad; to get book allocations from the National Library and other donors; to inspect and supervise subordinate libraries; to attend professional and officials meetings; to canvass books and other materials needed in the library.

5.3.1.3. Allowances as maybe provided by the local government unit.

5.3.2. Operational expenses to include office and janitorial supplies; subscription to periodicals; ; purchase of additional books; printing and binding; seminar expenses; communication services; repair and maintenance of office equipment; other sundry expenses.

5.3.3. Capital Outlay to cover the cost of needed furnishings and equipment from time to time.

5.3.4. The Library budget shall be adjusted annually as the need arises. 


\section{Standard 6. Collection}

6.1. The collection must reflect the objectives of the library and the needs of the community served.

6.2. It should include aside from books, periodicals, globes, maps, atlases pamphlets, clippings, various audio-visual materials like pictures, photos, charts, films, microforms, music scores, sound recordings, cassettes, tape reels, realias, dioramas, and other graphic materials.

6.3. Aside from the above, the library shall maintain a local history collection composed of materials about community, its history, resources, people, customs, traditions, etc.

6.4. The size of the book collection is dependent on the allocations given by

6.5. The National Library and the amount of budgetary appropriations available from the local government unit annually.

6.6. A minimum stack of 10,000 volumes regardless of population is deemed appropriate for a regional, provincial, city and first class municipal libraries.

6.7. For municipal libraries lower than first class, a book collection of 6,000 volumes is recommended while for barangay libraries 2,000 volumes.

6.8. The head librarian shall responsible for the selection and acquisition of all library material which should be based on the educational, informational, cultural and recreational needs of the community.

6.9. Emphasis is placed on those materials which best foster the sound development of the individual at all age levels.

\section{Standard 7. Physical Facilities}

7.1. Building

7.1.1. Site

7.1.1.1. The site of the building should centrally located within the community with provision for expansion for future growth.

7.1.1.2. It should be accessible to library users by all means of transportation.

7.1.1.3. In the development plan of the local government unit, it should be an integral part of an integrated cultural complex.

7.1.1.4. In the event that the building is inaccessible to a great majority of the reading public, at least one bookmobile unit should be provided and more barangay libraries should be established.

7.1.1.5. The building should as much as possible provide access to disabled

7.1.2. Size

7.1.2.1. The elements to considered in planning the size of the library building are the population or size of the community, the library collection, the size of the staff and budgetary appropriations.

7.1.2.2. Even in communities where the size of the population suggests a library many times larger than the existing or planned library, budgetary appropriations may force limitation on the size of the building. It is therefore wise to include plans for expansion for the future.

7.1.2.3. Each library should at least provide adequate space for bookshelves and reading areas, tables and chairs for library users, office tables and chairs for library personnel, workroom, multi-purpose room, storage, quarter for the personal needs of the staff and library furnishings and equipment.

7.1.2.4. Provision should be made for a minimum seating capacity of 100 per regional, provincial, city and first class municipal libraries; and at least 50 for other municipalities and 30 per barangay library.

7.1.2.5. Equipments and furnishing should be sufficient and adequate to generate a physical environment conductive for the pleasant and effective use of its materials and services.

7.1.2.6. Furniture should be functional and in harmony with the architecture of the building.

7.1.2.7. Equipment should be properly selected in such a way that will help in the efficient operation of the library activities.

7.1.2.8. Layout of equipment and furnishings should allow the smooth mobility of readers and materials.

7.1.2.9. Standards equipment and furnishings are as follows:

Atlas Stand

Charging desk

Book display rack

Dictionary Stand

Bookshelves

Newspaperrack

Cabinets, Filing

Tables, Office

Card Catalog Tables,

reading Carrels Table,

Typewriting Chairs,

Office Typewriter Chairs

reading Various hardware Equipment (when necessary)

\section{Standard 8. Library Services}

8.1. Library Services shall be provided with the highest degree of efficiency and integrity keeping in mind that the public library is a service agency of the government of the people.

8.2. The library shall reflect the needs of the community which shall include books, pamphlets, non-print as well as ephemeral materials classified and catalogued according to the standard procedures for easy retrieval.

8.3. Open shelves system shall be adopted to give library users free access to all materials in the collection except for some non-print materials which necessitates special handling.

8.4. The library shall provide wholesome materials for all types of readers in all age levels regardless of civic, cultural, ethnic, religious and political affiliations.

8.5. The library should collect local history materials for preservation and conservation.

8.6. Sufficient number of local newspapers and other periodicals should be acquired to keep the community abreast of national affairs as well as information on daily living. 
8.7. The library should have a written statement of it's objectives as well as its functions which should be reviewed periodically to keep up with the times and needs of the community.

8.8. There should be a well-planned hours of service to meet the needs of the community and maximize use of library resources and facilities.

8.9. Circulation of books for home use should be for periods as liberal as the collection permits.

8.10. The library should initiate or organize group activities within the framework of its own program. These activities could be storytelling, puppet shows book discussions, play reading, poetry interpretation lectures, demonstrations, exhibits, etc.

8.11. To promote the effective use of the library by the community, the library shall offer the following services according to their resources and facilities capability

8.11.1 Reference and research services.

8.11.2 Circulation of books for home use.

8.11.3 Organizing a library for children.

8.11.4 Reading guidance for children and out-of-school youths.

8.11.5 Compilation of periodical clippings on various government thrusts and other important subjects.

8.11.6 Indexing of periodicals.

8.11.7 To search and supply information needed by officials and offices of the local government units.

8.11.8 To compile and index various public documents made available by the local government and to disseminate those needed by the public.

8.11.9 Extension of library services to outreach areas.

8.11.10 Interlibrary loans with other public and school libraries.

8.11.11 Organizing extension libraries.

8.11.12 Operating bookmobile service when available.

\section{Standard 9. Reports and Inventory}

9.1 The library shall accomplish monthly statistical report as required by the National Library as a measure of its activities and accomplishments and shall furnish a copy to the local government unit.

9.2 Annual narrative and statistical reports are to be prepared for comparative studies and evaluation of its program and activities, copies of which are to be furnish the local government unit and the National Library.

9.3 The library shall develop a monitoring system of its operations and procedures to assess and evaluate from time to time its efficiency and its effectivity as a service agency of the government.

9.4 An annual inventory of resources shall be made to determine their loss if any, quality and serviceability. Report of their conditions shall be submitted to the proper governing authorities.

Prepared by:

Committee on Standards for Public Libraries.

(Sgd.) PILAR R. PEREZ

Chairman

(Sgd.) PRUDENCIANA C. CRUZ
Member $\begin{gathered}\text { (Sgd.) ATTY. CONRADO DAVID } \\ \text { Member }\end{gathered}$

Member

Implementing Rules and Guidelines of R.A. 7743

\section{Preliminary Article}

Pursuant to Section 2.5. and 9 of R.A. 7743. An Act Providing for the Establishment of Congressional, City, Municipal Librarian and Barangay Reading Centers throughout the Philippines, and with the view of implementing effectively the provisions of said Act, the following rules and regulations are hereby adopted.

\section{Article I}

\section{Definition of Terms}

\section{Section 1. Terms of Reference}

Barangay - the basic political unit which serves as the primary planning and implementing unit of government policies, plans, programs, projects, and activities in the community and as a forum wherein the collective views of the people may be expressed, crystallized and considered, and where disputes may be amicably settled.

Barangay Reading Center - a public library located in an established and maintained by a barangay and caters primarily to the library and information needs of barangay residents.

City - a political unit consisting of more urbanized and developed barangays and serves as a general purpose government for the coordination and delivery of basic, regular and direct services and effective governance of the inhabitants within its territorial jurisdiction.

City Library - a public library located, established, maintained and supported by the city government and primarily for the use of the residents of the city. Congressional District - otherwise known as legislative district is a geographical unit of a province or city which is comprised, as far as practicable of contiguous, compact and adjacent territory. Each city with a population of a least 250 thousand or province, shall have at least one representative. Congressional district library - a public library located within the congressional district established and maintained by the National Library and supported by the incumbent congressman of the district and primarily for the use of the residents of the district. 
Librarian - in the Philippine context, is any person who is bonafide holder of a license and a certificate of registration issued by the Professional Regulation Commission Board for Librarians in accordance with R.A. 6966.

Library - is a collection of books and similar material organized and administered for reading, consultation and study.

- a room, a group of rooms, or a building, in which a collection of books and similar material organized and administered for reading, consultation and study.

Municipality - a political units consisting of a group of barangays and serves primarily as a general purpose government for the coordination and delivery of basic, regular and direct services and effective governance of the inhabitants within its territorial jurisdiction.

Public Library - in these Guidelines, is a library located in, established and maintained by the barangay, municipality, city, province, or congressional district as the case may be and serves or caters primarily to their respective constituents.

\section{Article II}

\section{Establishment of Public Libraries and Reading Centers}

Section 2. A public library shall be established in every congressional district, city, and municipality in the country as a joint undertaking of the National Library, the Department of Interior and Local Government, the Philippine Information Agency, the local government unit and the citizens of the locality. Likewise, a barangay reading center shall be established in every barangay in the country.

Each district library shall maintain, as far as practicable is bookmobileunit which shall serve the library and information needs of far-flung in the district.

\section{Article III}

\section{Library Staff}

Section 3. In order to ensure the effective and efficient operation of the library, it shall be manned by professionally trained personnel with a support staff. It shall be staffed initially with the following.

1. Congressional district library

a) Congressional district librarian Educational requirement : M.A. in library Science degree or any Bachelor's degree major in Library Science. Experience : preferably with 2 years experience involving library administration and management. CPCB Item and Salary grade : Librarian III, SG 18.Training: 40 hours training in public library management and administration. Eligibility requirements: Librarian's License.

b) Librarian I Educational requirements : Any bachelor's degree major in library science. Salary Grade: 10 Eligibility: Librarian's License

c) Clerk Educational requirements: 2 - yr. Course Eligibility: Sub-professional CPCB Item and Salary grade: Clerk 1. SG. 3

d) Utility worker (CONTRACTUAL)

e) Librarian II (optional depending on the size of the library) Salary Grade: 14 Eligibility : Librarian's License

2. City Library:

a) Congressional district librarian Educational requirement : M.A. in library Science or any Bachelor's degree major in Library Science. Experience : preferably with 2 years experience involving library administration and management. CPCB Item and Salary grade : Librarian IV, SL 22. Training: 40 hours training in public library management and administration. Eligibility requirements: Librarian's License.

b) Librarian I Educational requirements : Bachelor's degree in Library science or any degree major in LS. . Salary Grade: 10 Eligibility: Librarian's License

c) Clerk Educational requirements: 2 - yr. Secretarial Course Eligibility : sub-professional CPCB Item and Salary grade: Clerk 1. SG1

3. Municipal Library

3.1. 1st Class Municipalities

a.) Municipal Librarian Educational requirements: Any degree major in Library Science Eligibility : R.A. 6956CPCB Item and Salary grade: Librarian III, SG18

3.2. 2nd Class Municipalities

a.) Municipal Librarian Educational requirements: Any degree major in Library Science Eligibility : Librarian's License CPCB Item and Salary grade: Librarian II, SG14

3.3. 3 Class Municipalities and below:

a.) Municipal LibrarianEducational requirements: Any degree major in Library Science Eligibility : Librarian LicenseCPCB Item and Salary grade: Librarian I, SG10

4. Barangay Reading Center

a.) Barangay Reading Center In-charge Educational requirements: 2-yr., course of college education. Eligibility : sub-professional Section 4. The number of staff in a public library may be increased as its services expand provided that such increase will be effected through a staffing pattern to be presented and duly endorsed by the National Library to the Department of Budget and Management for approval.

Section 5. Except for the Congressional District Librarian and staff whose appointments shall be issued by The National Library, all staff of the established city and municipal libraries and barangay reading centers shall be appointed and supervised by each local government unit through its chief executive (city mayor, municipal mayor, barangay captain) in coordination with their respective development council.

\section{Article IV}

\section{Role and Responsibilities of the National Library}

\section{Section 6.}

a) The National Library shall establish congressional district, city and municipal libraries and with the DILG, barangay reading centers for the next five years in accordance with the rules and regulations provided for in the law.

b) It shall provide books and other reading materials including government publications and library forms to public libraries which submit required 
reports regularly and promptly.

c) It shall orient and train newly appointed librarians primarily to make them aware of their responsibilities to the National Library, to their local government unit and to their library clientele.

d) It shall conduct regularly, seminars, workshops, in-service training programs to public librarians for professional growth and development.

e) It shall receive and process application and subsequently appoint all congressional district librarians and staff and shall supervise and monitor their performance.

f) It shall direct all congressional district librarians to come to Manila for periodical consultations, conference or meeting on issues/matters affecting the libraries under their jurisdiction.

\section{Article V}

\section{Role and Responsibilities of Local Government Units}

Section 7. It shall be the duty and responsibility of every congressional district, city, municipality and barangay to provide the following:

a) Library appropriation. A regular annual library appropriation to be drawn from certain percentage raised from amusement tax, realty tax, and other sources of local income shall be allocated based on the budget estimate proposed by the head librarian;

b) A separate building or room of adequate size; sufficient number of chairs, reading tables, bookshelves, audio-visual equipment, and all other necessary equipment for the effective operation of the library;

c) An adequate number of professional ad non professional library staff;

d) An up-to-date and adequate collection of books, serials periodicals, newspapers and other library materials to augment the annual allocation of The National Library.

\section{Article VI}

\section{Role and Responsibilities of the Department of Interior and Local Government (DILG)}

Section 9. It shall be the responsibility of the DILG to:

a) Assist in promoting the establishment of Congressional, City, and Municipal Libraries and Barangay Reading Centers nationwide;

b) Spearhead the organization of community reading clubs in every barangay;

c) Assist in evaluating needed requirements for accreditation of public libraries based on criteria and recommendation; and,

d) Assist in monitoring the progress of implementation of the Act specially barangay reading centers.

e) Network with various Foundation and organizations which donate books, magazines and other library materials and

f) Be responsible for the distribution to barangay libraries materials, books, etc., which may be solicited by The National Library, Philippines Information Agency of the Department of Interior and Local Government.

\section{Article VII}

Role and Responsibilities of the Philippines Information Agency (PIA)

Section 10. It shall be the duty and responsibility of the Philippine Information Agency (PIA) to:

a.) regularly provide the libraries with government documents that could be solicited for free;

b) provide Information Education and Communication (IEC) materials production assistance whenever funds are made available to PIA by the National Library and the Department of Interior and Local Government.

c) provide librarians with training on all aspects of communication information dissemination and,

d) make PIA Provincial Community Development centers serve as extension of provincial / municipal libraries for government oriented IEC materials.

\section{Article VIII}

\section{Appropriation}

Section 11. It shall be the responsibility of The National Library to include in its annual budget proposal starting in 1975 the amount of 1 million for each library to be established in a congressional district, the amount of five hundred thousand for a city library, three hundred thousand for a municipal library, and two hundred thousand pesos for a barangay reading center to be established. Provided that, the total amount proposed annually and for a period of 5 years shall be increased proportionally and shall be enough to fund for the total number of libraries to be established during each year in accordance with development plan. Subsequently, maintenance and operation thereof of these libraries shall be undertaken by their respective local government after the five-year period except for congressional district libraries which shall be maintained continuously by The National Library. However, The National Library shall continue to provide all these libraries with annual allocation of books and other library materials. Further, the appropriations for the establishment of barangay reading centers maybe integrated with the regular appropriations of the Department of Interior and Local Government (DILG).

\section{Article IX}

\section{Memorandum of Agreement}

Section 12. A memorandum of agreement (MOA) shall be executed between The National Library as the lead agency and the respective local government unit there a public library shall be established to define clearly the roles of the respective agencies and to ensure the sustainability or continued existence of the library even during a change of election local officials.

The DILG, represented by the Regional Director shall be made co-signatory of the local government unit in the MOA. 


\section{Article X}

\section{Library Board and Friends of the Library}

Section 13. Local Library Board. A Local Library Board shall be organized in every public library to symbolize the democratic character of the library and shall be appointed by publicly elected officials. The Board shall act as advisory and policy-setting authority but can provide stability and continuity especially during changing times.

Section 14. Creation and Composition

a) There shall be establishment in every district, city, municipality or barangay a district city, municipality, or barangay library board respectively.

b) The composition of local library boards shall be as follows:

1) The Congressional district library board shall be composed of the incumbent Congressman as Chairperson; the Municipal Mayors of the District Library as members, and the District librarian as Secretary.

2) The City library board shall be composed of the city mayor as Chairperson; the chairman of the Committee on Education and Culture of the Sangguniang Panlunsod, the City Treasurer, the City Budget Officer, the representative of the pederasyon ng mga sangguniang kabataan in the sangguniang panlunsod, the elected president of the Friends of the City Library as members and the City Librarian as Secretary.

3) The Municipal Library Board shall be composed of the municipal mayor as Chairperson; the representative of the pederasyon ng mga sangguniang kabataan in the sangguniang bayan, the president of the friends of the Municipal Library, the Municipal Treasurer as members, and the Municipal Librarian as Secretary.

4) The Barangay Library Board shall be composed of the Barangay Captain as Chairperson; the Chairman of the Education Committee and representative of the youth in the Barangay Council, the barangay library in-charge, the Barangay Treasurer, the duly elected president of the Friends of the Library or book clubs, to present non-government organization (NGO), as members and the Barangay Reading Center in-charge as Secretary.

The performance of the duties and responsibilities of the above-mentioned officials in their respective local library board shall not be delegated.

Section 15. Functions of Local Library Boards. - The Congressional district, city, municipal or barangay library board shall:

a) Determine, in accordance with the criteria set by The National Library, the annual supplementary budgetary needs for the operation and maintenance of library within the congressional district, city, municipality, or barangay as the case may be, and supplementary local cost of meeting such needs, which shall be reflecting in the form of an annual library board budget;

b) Authorize the treasurer as to disburse funds pursuant to the budget prepared and in accordance with existing rules and regulations;

c) To serve as an advisory committee to the Sanggunian concerned on library matters - such as but not limited to the necessary for and application of local appropriations for public library purposes;

d) Create committees which shall advice local library agencies on matters such as, but not limited to personnel selection and promotion, bids, and awards, grievances and complaints, personnel discipline, budget review, operations review and similar functions,

e) To find ways \& means in increasing the book \& non-book collections of the library and in improving the facilities of the library.

Section 16. Meetings and Quorum Budget Compensation and Remuneration

a) Meeting of the Board shall be held 2 times a year and shall be called by the chairperson. However, special meeting maybe scheduled as the need arises. A majority of all its members shall constitute a quorum. The District librarian, the city librarian or the municipal librarian, or the barangay reading center in-charge as the case may be, shall prepare the library budget concerned. Such budget shall be supported by programs, projects, and activities of the library board for the ensuing fiscal year. The affirmative vote of the majority if all the members shall be necessary to approve the budget.

Section 17. Compensation and Remuneration. - The co-chairman, and members of the congressional district, city or municipal library board shall perform their duties as such without compensation or remuneration. Members thereof who are not officials or employees shall be entitled to necessary traveling expenses and allowance chargeable against the funds of the local library board concerned, subject to existing accounting and auditing rules and regulations.

Section 18. Friends of the Public Library. The Local Library Board shall organize The Friends of the Public Library to support the projects and activities of the library especially those concerning financial support.

\section{Article XI}

\section{Inter - Agency Committee}

Section 19. Creation and Composition. An national inter - agency committee shall be organized to be composed of a) The National Library; b) The Department of Interior and Local Government; c) The Philippine Information Agency.

Section 20. Functions and Duties

a) The Inter - agency committee shall serve as the consultancy body to hasten the implementation of the Law.

b) It shall serve as the oversight committee which shall study recommend amendment of the Law to the proper body.

\section{Article XII}

\section{Effectivity}

Section 21. These herein Rules and Regulations shall take effect fifteen (15) days following the completion of its publication in the official Gazette or in a 
ISSN: 2239-978X

E-ISSN: 2240-0524
Journal of Educational and Social Research MCSER Publishing, Rome-Italy
Vol. 3 No. 3

September 2013

newspaper of general circulation.

Done in the city of Manila this _ 5 th _ day of _ October _, 1994

(Sgd.) ADORACION M. BOLOS

Actg. Director

The National Library

(Sgd.)RAFAEL ALUNAN, II

Secretary

Department of Interior \& Local Government

(Sgd.) HONESTO ISLETA

Press Undersecretary and Officer-in-charge

Philippine Information Agency 